Indonesian Journal of Medicine (2019), 4(4): 354-363

https://doi.org/10.26911/theijmed.2019.04.04.08

\title{
Relative Efficacy of Probiotics Compared with Oral Rehydration Solution for Diarrhea Treatment in Children under Five Years Old: a Meta-Analysis from Developing Countries
}

\author{
Nurul Aini Suria Saputri' ${ }^{1)}$, Tri Nugraha Susilawati'), Vitri Widyaningsih") \\ 1)Masters Program in Public Health, Universitas Sebelas Maret \\ 2)Faculty of Medicine, Universitas Sebelas Maret
}

\begin{abstract}
Background: Children under five experience an average of three episodes of diarrhea each year in developing countries. Based on World Health Organization (WHO) guidelines, therapy for acute diarrhea is oral rehydration fluid and zinc to treat fluid and electrolyte loss. But unfortunately, this therapy does not reduce the duration of diarrhea without the intestinal barrier function of pathogenic microorganisms. The ability to inhibit pathogens is one of the three main mechanisms of probiotics. This study aims to examine the efficacy of using probiotics compared to oral rehydration solution (ORS) in the treatment of acute diarrhea in children under five in developing countries.

Subjects and Method: This study is a meta-analysis conducted using PRISMA systematic guidelines. The process of searching for articles was carried out between 2009 and 2019 using a database search engine consisting of PubMed, British Medical Journal (BMJ), CAB Direct, Oxford Academy, Clinical Key, ScienceDirect, and Scopus. Based on a database search, six articles that meet the criteria of the Randomized Controlled Trial (RCT) and research conducted in developing countries were found. The study involved 1234 children who were divided into two groups: 762 probiotic groups and 472 ORS groups. The analysis was performed with the Review Manager (RevMan) software 5.3. The results were assessed using Standardized Mean Difference (SMD).

Results: There was heterogeneity between experiments (I2 = 91\%; $\mathrm{p}<0.001$ ) so Random Effects Model (REM) was used. Probiotics could reduce the duration of acute diarrhea in infants rather than just ORS, with a pooled estimate of 1.13 (SMD $=-1.13$; 95\% $\mathrm{CI}=-1.54$ to $-0.72 ; \mathrm{p}<0.001$ ).

Conclusion: Probiotics can reduce the duration of acute diarrhea in infants in developing countries rather than just the administration of ORS.
\end{abstract}

Keywords: Diarrhea, probiotics, oral rehydration solution, meta-analysis.

\section{Correspondence:}

Nurul Aini Suria Saputri. Masters Program in Public Health, Universitas Sebelas Maret. Jl. Ir. Sutami 36 A, Surakarta 57126, Central Java. Email: ainisuriasaputri@gmail.com. Mobile: 085743401971

\section{BACKGROUND}

Diarrheal disease is still a major cause of morbidity and mortality in children under five. Diarrhea is the second highest cause of death of children under the age of five years worldwide (WHO, 2017). Children under five experience an average of three episodes of diarrhea each year in developing countries. Each episode of diarrhea leaves the child deficient in the nutrients needed for growth and development. As a result, diarrhea is a major cause of mal-nutrition events. Children who are malnourished will be more susceptible to diarrhea (WHO, 2017).

The percentage of estimated underfive mortality due to diarrhea has decreased from 2009 to 2016 (UNICEF, 2018). The prevalence of diarrhea in children under five in Indonesia decreased from $18.5 \%$ to 
$12.3 \%$ of the results of Riskesdas 2013 (Riskesdas, 2018).

Diarrheal disease is a disruption of defecation process (defecation/chapter), where the process occurs more than three times and is thin (WHO, 2017). WHO (2017) states there are three types of diarrhea, including: acute liquid diarrhea, which lasts several hours or several days, and includes cholera; acute diarrhea accompanied by blood, also called dysentery; and persistent diarrhea, which lasts 14 days or more. Acute diarrhea kills more than 1.5 million children under five every year globally and is the diarrhea most commonly experienced by children under five.

Based on World Health Organization (WHO) guidelines, therapy for acute diarrhea is oral rehydration fluid and zinc which aims to overcome fluid and electrolyte loss. But unfortunately, this therapy does not reduce the duration and frequency of diarrhea without the intestinal barrier function of pathogenic microorganisms. The ability to inhibit pathogens is one of the three main mechanisms of probiotics in addition to improving intestinal barrier function and immune interactions (WHO, 2017).

The use and variety of probiotic products is growing. Some differences in the situation between developed and developing countries such as sanitation, exclusive breastfeeding, socioeconomic level, parental education, and climate are thought to influence the effectiveness of probiotics (Rahmi and Gayatri, 2015).

Currently, the use of probiotics as adjunctive therapy in the treatment of diarrhea has been widely practiced in Indonesia. The meta-analysis conducted by Rah$\mathrm{mi}$ and Gayatri (2015), concludes that studies of the effectiveness of probiotic administration in acute diarrhea are still diverse, although most show the effectiveness in reducing the duration and frequency of diarrhea. This may be influenced by probiotic strains given. Research is needed to assess the long-term effects of probiotics and how acute diarrhea recurrence rates after administration of probiotic therapy (Rahmi and Gayatri, 2015).

This study aims to examine the efficacy of using probiotics compared to oral rehydration solution (ORS) in the treatment of acute diarrhea in children under five in developing countries.

\begin{tabular}{l}
\hline SUBJECTS AND METHOD \\
\hline a. Study Design \\
This study is a systematic review and meta- \\
analysis study. The study was conducted \\
using secondary data in the form of data \\
from the results of previous studies that \\
were limited in the period from 2009 to \\
2019. The data was sought from a syste- \\
matic and comprehensive database of seve- \\
ral indexing including; PubMed, British \\
Medical Journal (BMJ), CAB Direct, Oxford \\
Academy, Clinical Key, ScienceDirect, and \\
Scopus. This is done by using keywords for \\
database search namely "efficacy" and \\
"safety" and "probiotic" and "acute" and \\
"diarrhea or diarrhea" and "children".
\end{tabular}

\section{b. Population and Sample}

The dependent variable is acute diarrhea under five. The independent variable is the provision of probiotics. This study involved two treatment groups which were then compared. The intervention group is probiotics and the control group is ORS. The outcome measure of probiotics and ORS is the duration of diarrhea.

The inclusion criteria in this study were full paper articles with Randomized Controlled Trial (RCT). The therapy given is probiotics with ORS comparison. Subjects were toddlers (0-5 years) with acute diarrhea in developing countries. The article was published in English. 
The exclusion criteria in this study were that the study was conducted with a systematic review, meta-analysis, cross sectional, case control, quasi-experimental. The interventions given were in the form of fermented foods (for example yogurt) that did not include the types of probiotic strains contained in them.

\section{c. Study Variables}

Acute diarrhea in infants is defecation in children under five that occurs in frequency more than three times in 24 hours and is thin, and occurs in duration $<14$ days.

Probiotic therapy is a probiotic that is given as an additional therapy in treating acute diarrhea in infants in a single dosage form or in combination.

\section{d. Study Instrument}

The instruments used to collect this data were published articles between 2009 and 2019 with research carried out in developing countries contained in databases including; PubMed, British Medical Journal (BMJ), CAB Direct, Oxford Academy, Clinical Key, ScienceDirect, and Scopus.

\section{e. Data Analysis}

Data analysis was performed using Review Manager (Rev-Man) 5.3 software released by the Cochrane Collaboration. RevMan is used to calculate the Standardized Mean Difference (SMD) as a whole.

\section{RESULTS}

The data were sought from a systematic and comprehensive database of several indexing including; PubMed, British Medical Journal (BMJ), CAB Direct, Oxford Academy, Clinical Key, ScienceDirect, and Scopus. The results of the article search show that there were 1052 articles identified and it can be seen in Figure 1. After going through the process of removing multiple articles amounting to 69 articles, the articles filtered becoming 983 articles. Based on the results of the filtered articles there were 934 articles that had to be excluded and 48 articles were found that were considered to be eligible for a full text review process.

After a full text article review, articles with research conducted not in developing countries, namely in China, the United States, Canada, South Korea, Poland, Australia and Italy were found. Subjects in the studies were not toddlers. The research variables were not appropriate, namely not probiotics with specific strains and not acute diarrhea. The outcome of the study did not meet the requirements because it was not the duration of diarrhea but the frequency of diarrhea, volume of diarrhea, cost-effective treatment, and others. The comparison is not ORS but placebo and standard therapy. Articles that meet the qualitative requirements are reviewed and two articles are excluded because they do not include the average duration (mean duration) and standard deviation (SD) needed to determine the effect of the treatment. The article only includes differences in improvement after treatment so that it cannot be analyzed using Standardized Mean Difference (SMD).

The final results of the article review process show there are six articles that meet the quantitative requirements for a metaanalysis of the effectiveness of the administration of probiotics in the management of acute diarrhea in infants. Articles obtained from the results of the review, is a study that came from countries included in developing countries. The following is an overview of the research areas obtained from articles that have fulfilled the requirements: There are four studies conducted in Turkey, and each one is in India and Bolivia.

Turkey has the most research related to the efficacy of probiotics, involving 363 children receiving probiotics and 262 
children receiving ORS. The Indian state involved 374 children receiving probiotics and 185 children receiving ORS. The Bolivian state involved 25 children receiving probiotics and 25 children receiving ORS.

The results of the meta-analysis are presented in the form of a forest plot. A forest plot is a diagram showing information from each of the studies studied and an estimate of overall results. In addition to forest plots, funnel plots are also presented, which are diagrams that illustrate the possibility of publication bias by displaying the relationship between the effect size of the study and the sample size of the various studies studied. The existence of publication bias in the funnel plot can be assessed by looking at the asymmetry of the funnel shape, and the number of points found on the right and left side compared to the standard error (Murti, 2018).

Based on the articles identified from the review results, 6 articles were qualified as a source for a meta-analysis of the efficacy of using probiotics compared to ORS in reducing the duration of acute diarrhea in children under five. Furthermore, the articles that have been obtained will be analyzed using RevMan 5.3 and the results will be presented in the form of a forest plot that can be seen in Figure 2 .

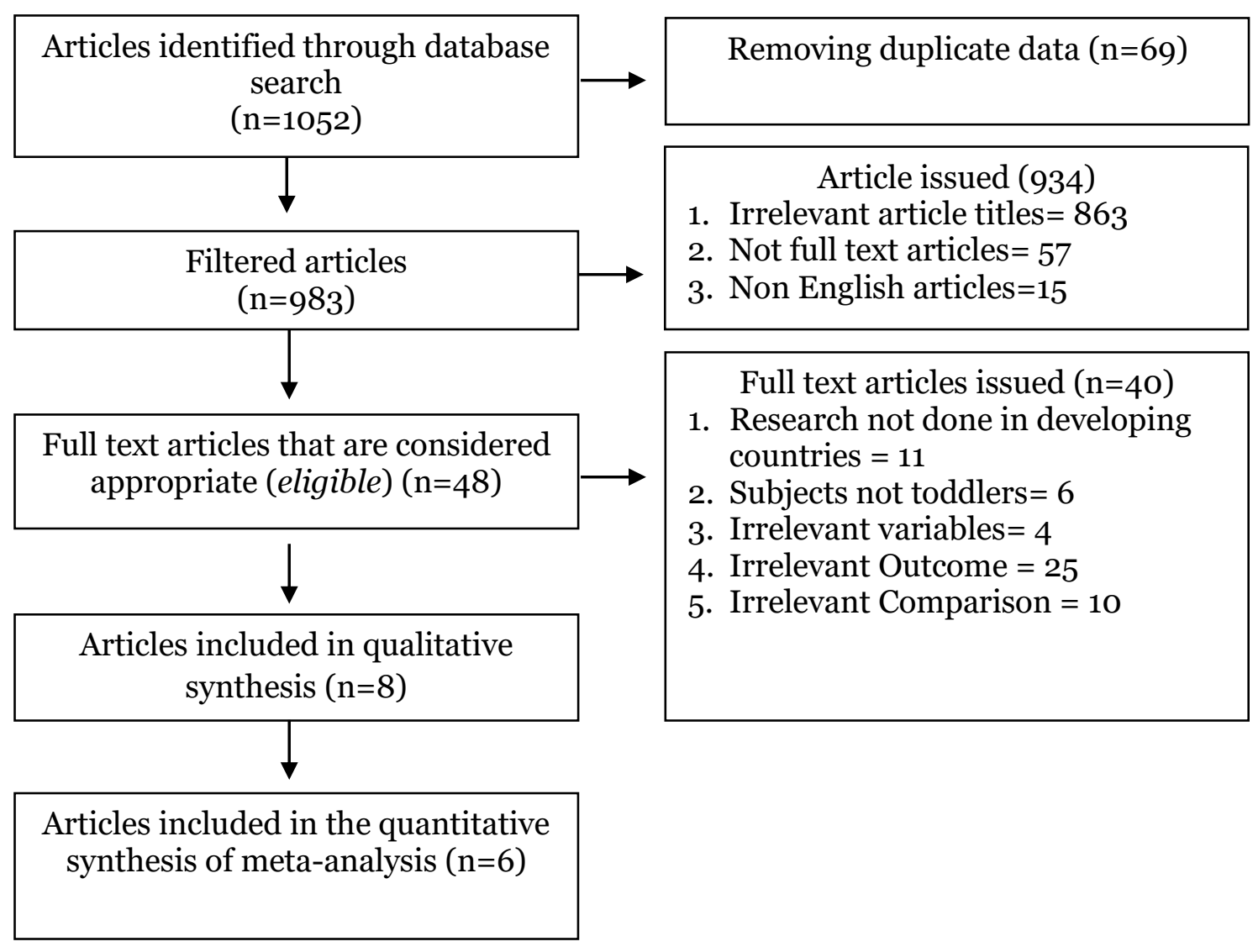

Figure 1. Flowchart of Review Process 
Indonesian Journal of Medicine (2019), 4(4): 354-363

https://doi.org/10.26911/theijmed.2019.04.04.08

Table 1. Summary of the source of administration of probiotics vs ORS to the incidence of acute diarrhea toddlers

\begin{tabular}{|c|c|c|c|c|c|c|}
\hline \multirow{2}{*}{ Author (Year) } & \multirow{2}{*}{ Country } & \multicolumn{2}{|l|}{ Group } & \multirow{2}{*}{ Inclusion Criteria } & \multicolumn{2}{|l|}{ Hasil } \\
\hline & & Intervention & Control & & Intervensi & Kontrol \\
\hline (Basu et al., 2009) & India & $\begin{array}{l}L G G \text { powder } \\
\text { containing10 } \\
\text { cfu }\end{array}$ & ORS & $\begin{array}{l}\text { The subjects were under-fives who } \\
\text { were treated in a child's ward with } \\
\text { a diagnosis of acute watery } \\
\text { diarrhea (AWD) in North Bengal } \\
\text { Medical College and Hospital, } \\
\text { Darjeeling. }\end{array}$ & $\begin{array}{l}\text { Mean: } 5.02 \\
\text { SD: } 1.32\end{array}$ & $\begin{array}{l}\text { Mean: } 7.23 \\
\text { SD: } 1.27\end{array}$ \\
\hline $\begin{array}{l}\text { (Basu et al., 2009- } \\
\text { 2) }\end{array}$ & India & $\begin{array}{l}L G G \text { powder } \\
\text { containing } 10^{12} \mathrm{cfu}\end{array}$ & ORS & $\begin{array}{l}\text { The subjects were children under } \\
\text { five who were treated in the wards } \\
\text { of children with a diagnosis of } \\
\text { acute watery diarrhea (AWD) in } \\
\text { Department of Pediatrics, North } \\
\text { Bengal Medical College and } \\
\text { Hospital, Darjeeling. }\end{array}$ & $\begin{array}{l}\text { Mean: } 5.12 \\
\text { SD: } 1.16\end{array}$ & $\begin{array}{l}\text { Mean: } 7.23 \\
\text { SD: } 1.27\end{array}$ \\
\hline $\begin{array}{lll}\text { (Teran } & \text { et } & a l ., \\
\text { 2009) } & & \end{array}$ & Bolivia & $\begin{array}{l}\text { Combination } \\
\text { Probiotics } \\
\text { Lactobacillus } \\
\text { acidophilus, } \\
\text { Lactobacillus } \\
\text { rhamnosus, } \\
\text { Bifidobacterium } \\
\text { longum, } \\
\text { Saccharomyces } \\
\text { boulardii } \\
\end{array}$ & ORS & $\begin{array}{l}\text { Infants aged } 28 \text { days to } 24 \text { months, } \\
\text { with a history of acute liquid } \\
\text { diarrhea (rotavirus positive) lasting } \\
\text { less than } 72 \text { hours and moderate to } \\
\text { severe dehydration. }\end{array}$ & $\begin{array}{l}\text { Mean: 57.1 SD: } \\
25.4\end{array}$ & $\begin{array}{l}\text { Mean: } 74.6 \\
\text { SD: } 26.6\end{array}$ \\
\hline $\begin{array}{l}\text { (Erdogan et al., } \\
\text { 2012) }\end{array}$ & Turkey & $\begin{array}{l}\text { Saccharomyces } \\
\text { boulardii }\end{array}$ & ORS & $\begin{array}{l}\text { Pediatric patients aged between } \\
\text { five months to five years who are } \\
\text { treated for acute diarrhea and } \\
\text { diagnosed as rotavirus } \\
\text { gastroenteritis. }\end{array}$ & $\begin{array}{l}\text { Mean: } 6.6 \\
\text { SD: } 1.7\end{array}$ & $\begin{array}{l}\text { Mean: } 7 \\
\text { SD: } 1.6\end{array}$ \\
\hline $\begin{array}{l}\overline{\text { (Erdogan }} \text { et al., } \\
\text { 2012-2) }\end{array}$ & Turkey & $\begin{array}{l}\text { Bifidobacterium } \\
\text { lactis }\end{array}$ & ORS & $\begin{array}{l}\text { Pediatric patients aged between } \\
\text { five months to five years who are } \\
\text { treated with acute diarrhea and } \\
\text { diagnosed as rotavirus } \\
\text { gastroenteritis. }\end{array}$ & $\begin{array}{l}\text { Mean: 4.1 SD: } \\
1.3\end{array}$ & $\begin{array}{l}\text { Mean: } 7 \\
\text { SD: } 1.6\end{array}$ \\
\hline
\end{tabular}


Table 1. Summary of sources of probiotics $v$ s ORS for acute under five diarrhea events (continued)

\begin{tabular}{|c|c|c|c|c|c|c|}
\hline \multirow{2}{*}{ Author (Year) } & \multirow{2}{*}{ Country } & \multicolumn{2}{|l|}{ Group } & \multirow{2}{*}{ Inclusion Criteria } & \multicolumn{2}{|l|}{ Hasil } \\
\hline & & Intervention & Control & & Intervensi & Kontrol \\
\hline (Dinleyici et al., 2014) & Turkey & $\begin{array}{l}\text { Lactobacillus } \\
\text { reuteri } 17938\end{array}$ & ORS & $\begin{array}{l}\text { Pediatric patients aged between } \\
\text { three to } 60 \text { months, with acute } \\
\text { liquid diarrhea lasting } 12-72 \text { hours } \\
\text { and being treated at } 11 \text { Turkish } \\
\text { Centers. }\end{array}$ & $\begin{array}{l}\text { Mean: } 70.7 \\
\text { SD: } 26.1\end{array}$ & $\begin{array}{l}\text { Mean: } \\
103.8 \\
\text { SD: } 28.4\end{array}$ \\
\hline (Dinleyici et al., 2015) & Turkey & $\begin{array}{l}\text { Lactobacillus } \\
\text { reuteri DSM } \\
17938\end{array}$ & ORS & $\begin{array}{l}\text { Pediatric patients aged between } \\
\text { three to 6o months who come to } \\
\text { outpatient clinics with acute } \\
\text { infectious diarrhea, and who are } \\
\text { followed up with outpatient care at } \\
11 \text { Turkish Centers. }\end{array}$ & $\begin{array}{l}\text { Mean: } 60.4 \\
\text { SD: } 24.5\end{array}$ & $\begin{array}{l}\text { Mean: } 74 \cdot 3 \\
\text { SD: } 15 \cdot 3\end{array}$ \\
\hline $\begin{array}{l}\text { (Dinleyici et al., 2015- } \\
\text { 2) }\end{array}$ & Turkey & $\begin{array}{l}\text { Saccharomyces } \\
\text { boulardii CNCM } \\
\text { I-74 }\end{array}$ & ORS & $\begin{array}{l}\text { Pediatric patients aged between } \\
\text { three to } 60 \text { months both children } \\
\text { who are hospitalized or outpatient } \\
\text { with clinical signs of mild to } \\
\text { moderate dehydration. }\end{array}$ & $\begin{array}{l}\text { Mean: } 75.4 \\
\text { SD: } 33.1\end{array}$ & $\begin{array}{l}\text { Mean: } 99.8 \\
\text { SD: } 32.5\end{array}$ \\
\hline
\end{tabular}


Indonesian Journal of Medicine (2019), 4(4): 354-363

https://doi.org/10.26911/theijmed.2019.04.04.08

The results of the analysis in Figure 2 show that 6 articles with 6 study groups and 2 subgroups reporting that administration of probiotics can reduce the duration of acute diarrhea in infants. Based on the analysis results, there is heterogeneity between experiments (I2 $=91 \%$; $\mathrm{p}<0.001$ ) so that the Random Effects Model (REM) is used. Probiotics could reduce the duration of acute diarrhea in infants rather than just
ORS, with a pooled estimate of $1.13(\mathrm{SMD}=$ $-1.13 ; 95 \% \mathrm{CI}=-1.54$ to $-0.72 ; \mathrm{p}<0.001$ ).

Based on Figure 3, funnel plots giving probiotics vs. ORS in the management of diarrhea, plots on the right and left are not symmetrical with each other and do not form inverted funnels. The left plot has a standard error $>0.3$ and the right plot has a standard error $<0.3$. This indicates that in this study there was a publication bias in the study.

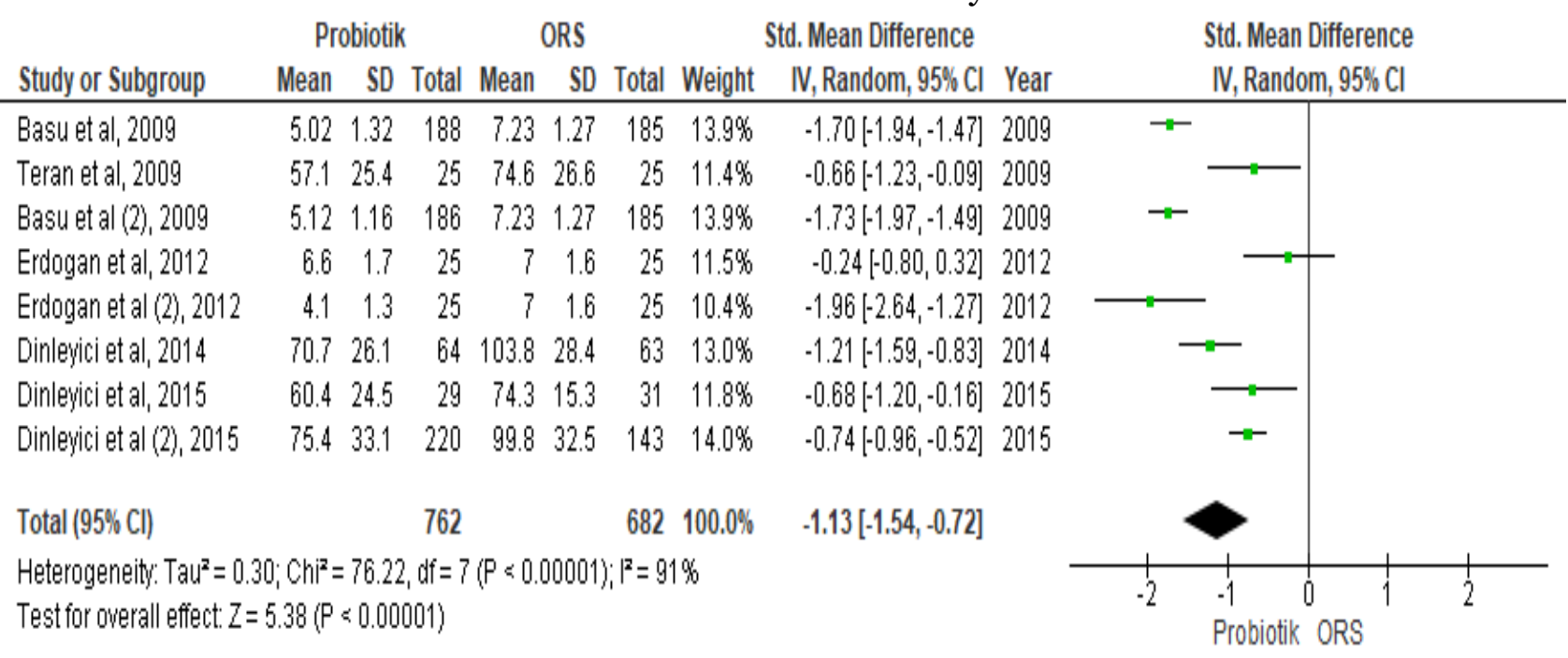

Figure 2. Forest Plots Probiotics vs. ORS for Diarrhea Management

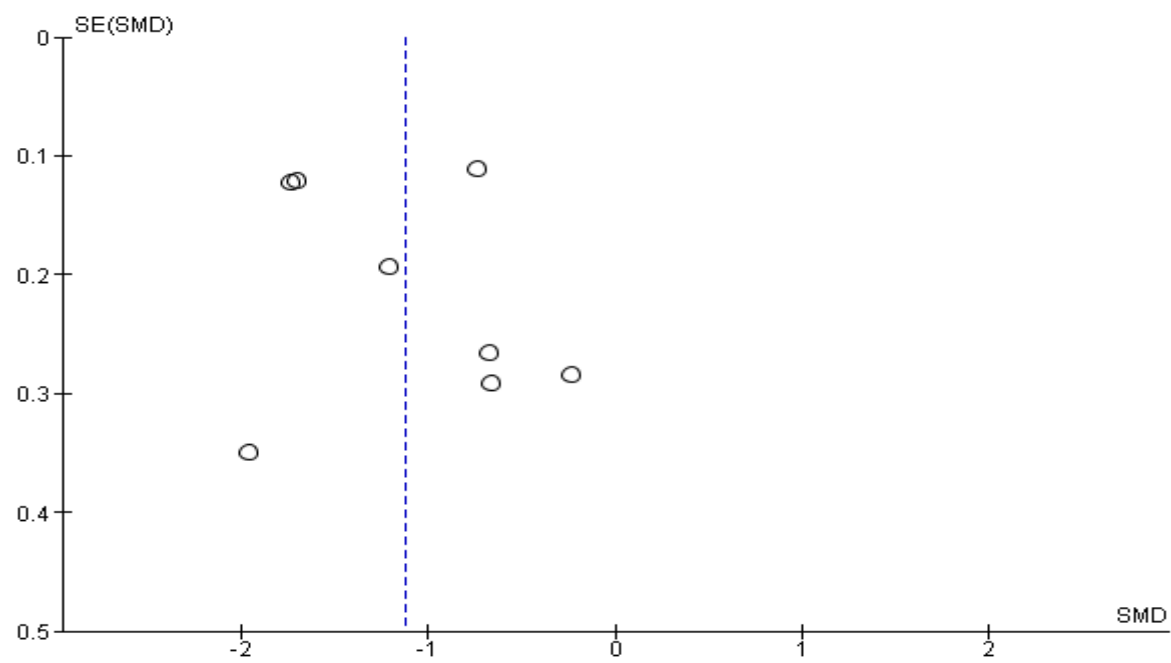

Figure 3. Funnel Plot Provision of Probiotics vs. ORS in the Management of Diarrhea

\section{DISCUSSION}

Children under five experience an average of three episodes of diarrhea each year in developing countries (WHO, 2017). Based on its duration, diarrhea can be classified into 3 categories: (1) acute diarrhea, 
diarrhea with duration of less than 2 weeks, (2) persistent diarrhea, diarrhea with a duration varying from 2 to 4 weeks, and (3) chronic diarrhea, diarrhea with duration of more than four weeks (Barai et al., 2018).

At the individual level, acute diarrhea causes interference with intestinal absorption of micronutrients and macronutrients, malnutrition, and inadequate growth. Treatment of acute diarrhea is a challenge for public health. Simple, safe, and costeffective interventions to treat acute diarrhea and prevent adverse effects on health will have considerable implications especially in developing countries (Basu et al., 2009).

Based on the results of an analysis of 6 articles, it was reported that the administration of probiotics could reduce the duration of acute diarrhea in infants rather than only the administration of ORS, with a pooled estimate of $1.13(\mathrm{SMD}=-1.13 ; 95 \%$ $\mathrm{CI}=-1.54$ to $-0.72 ; \mathrm{p}<0.001)$. The results of this meta-analysis are supported by a study by Ahmadi et al. (2015) which showed the positive effect of LGG probiotics and several other probiotics in reducing the duration of acute diarrhea due to rotavirus with $\mathrm{MD}=$ 0.41 (95\% CI $=-0.56$ to $-0.25 ; \mathrm{p}<0.001$ ). Szjaweska et al. (2013) conducted a metaanalysis related to the use of LGG. Lactobacillus $G G$ significantly decreases the duration of diarrhea (MD = 1.05 days, 95\% $\mathrm{CI}=1.7$ to 0.4 ) and is more effective when used in daily doses of $101010 \mathrm{cfu}(\mathrm{MD}=1.11$ days, $95 \% \mathrm{CI}=1.91$ to 0.31 ). The results of a meta-analysis of Szjaweska et al. (2013) also mentioned that LGG was effective in treating children's diarrhea in Europe ( $\mathrm{MD}=1.27$ days, $95 \% \mathrm{CI}=2.04$ to 0.49 ). In line with this study, LGG can also be said to be effective in reducing duration significantly in children with acute diarrhea in developing countries.
A similar study conducted by Canani et al. (2007) revealed that the duration of diarrhea was significantly lower in children who received LGG and a combination of probiotics compared to patients given ORS treatment alone (Erdogan et al., 2012). This probiotic affects the intestinal ecosystem by affecting the mucosal immune mechanism. This is done through interactions with commensal or potential pathogenic microbes, and produces metabolic end products such as short chain fatty acids. Interaction is done by communicating with host cells through chemical signaling. This mechanism can lead to potential pathogen antagonisms, a better intestinal environment, strengthen intestinal obstructions, reduce inflammation, and improve the regulation of the immune response to antigens. This phenomenon is considered to mediate the reduction in the incidence and severity of diarrhea (WGO, 2017).

Based on the results of the analysis related to the heterogeneity of research on the use of probiotics and ORS, there was a fairly high heterogeneity between experiments (I2 = 91\%; $\mathrm{p}<0.001)$. This is related to several conditions such as differences in the number of samples studied in each study, different types of probiotics used, differences in dosage and mode of administration. The number of samples in each study varied from 50 children to the most examined subjects of 370 children.

Of the six research articles reviewed, single strain probiotics are more widely used than combination probiotics. The most widely used probiotic types are Lactobacillus (Lactobacillus acidophilus, Lactobacillus rhamnosus GG and Lactobacillus reuteri 17938) and Bifido-bacterium (Bifidobacterium longum, and Bifidobacterium lactis). The types of probiotic strains most widely used are Saccharomyces boulardii and Lactobacillus rhamnosus GG (Basu et 
al., 2009; Dinleyici et al., 2015; Erdogan et al., 2012; Teran et al., 2009).

Despite these variations, probiotics are still significantly beneficial in reducing the duration of acute diarrhea in infants compared to ORS alone. For the development of probiotics as additional therapy, it is hoped that other researchers can conduct research related to more specific probiotic strains so that the benefits of probiotics can be targeted according to the type of diarrhea.

\section{AUTHOR CONTRIBUTION}

Nurul Aini Suria Saputri acted as the main researcher who collects and processes research data; Tri Nugraha Susilawati and Vitri Widyaningsih conducted a research paper review.

\section{FUNDING AND SPONSORSHIP}

This study does not use costs due to secondary data and uses a database that can be accessed and provides open access journals.

\section{CONFLICT OF INTEREST}

There is no conflict of interest in this study.

\section{REFERENCE}

Ahmadi E, Navaei RA, Rezai MS (2015). Efficacy of probiotic use in acute rotavirus diarrhea in children: A systematic review and meta-analysis. Caspian J Intern Med. 6(4): 187-195. Retrieved from: https://link.springer.com/referenceworkentry/10.1007\%2F978-3-319-29489-6234

Barai P, Hossain KM, Gazi MS (2018). Antidiarrheal efficacy of probiotic bacteria in castor oil induced diarrheal mice. Prev Nutr Food Sci. 23(4): 294-300. doi:10.1097/MCG.obo13e31815a578o.
Basu S, Paul DK, Ganguly S, Chatterjee M, Chandra PK (2009). Efficacy of highdose Lactobacillus rhamnosus $G G$ in controlling acute watery diarrhea in Indian children a randomized controlled trial. J Clin Gastroenterol. 43(3): 208-213. doi: 10.1097/MCG.obo13e31815 a5780.

Dinleyici EC, Dalgic N, Guven S, Metin O, Yasa O, Kurugol Z, et al. (2015). Lactobacillus reuteri DSM 17938 shortens acute infectious diarrhea in a pediatric outpatient setting. J Pediatr. 91(4): 392-396. doi: 10.1016/j.jped.2014.10.009.

Dinleyici EC, Kara A, Dalgic N, Kurugol Z, Arica V, Metin O, et al. (2015). Saccharomyces boulardii CNCM I-745 reduces the duration of diarrhoea, length of emergency care and hospital stay in children with acute diarrhoea. Benef Microbes. 6(4): 415-421. doi: 10.3920/BM2014.0086.

Dinleyici EC, Vandenplas Y, PROBAGE Study Group (2014). Lactobacillus reuteri DSM 17938 effectively reduces the duration of acute diarrhoea in hospitalised children. Acta Paediatr. 103: e300-e305. doi:10.1111/apa.12 617.

Erdogan O, Tanyeri B, Torun E, Gonullu E, Arslan H, Erenberk U, Oktem F (2012). The comparition of the efficacy of two different probiotics in rotavirus gastroenteritis in children. J Trop Med. 2012: 1-5. doi:10.1155/2012/787240.

Ministry of Health RI (2018). Hasil utama RISKESDAS 2018 (Main results of 2018 RISKESDAS). Kementerian Kesehatan Republik Indonesia: Badan Penelitian dan Pengembangan Kesehatan. Retrieved from: https://www.depkes.go.id > download > info-terkini > hasil riskesdas 2018. 
Murti B (2018). Prinsip dan metode riset epidemiologi, Edisi IV (Principles and methods of epidemiological research, Fifth Edition). Karanganyar: Bintang Fajar Offset.

Rahmi D, Gayatri P (2015). Laporan kasus berbasis bukti: manfaat pemberian probiotik pada diare akut (Evidencebased case reports: the benefits of giving probiotics in acute diarrhea). Sari Pediatri. 17(1): 76-80. doi: 10.14238/sp17.1.2015.76-80.

Szajewska H, Skorka A, Ruszczynski M \& Gieruszczak-Białek D (2013). Metaanalysis: Lactobacillus $G G$ for treating acute gastroenteritis in children-updated analysis of randomised controlled trials. Aliment Pharmacol Ther. 38(5): 467-476. doi: 10.1111/apt.12403.

Teran CG, Escalera CNT, Villarroel P (2009). Nitazoxanide vs. probiotics for the treatment of acute rotavirus diarrhea in children: a randomized, single-blind, controlled trial in Bolivian children. Int J Infect Dis. 13: 518523. doi:10.1016/j.ijid.2008.09.014.

UNICEF (2018). Diarrhoea remains a leading killer of young children, despite the availability of a simple treatment solution. Retrieved from: https://data.unicef.org/topic/childhealth/diarrhoeal-disease/e32.

WGO (2017). World gastroenterology organisation global guidelines: probiotics and prebiotics. Retrieved from: https://www.worldgastroenterology.org/guidelines/global-guidelines/probiotics-and-prebiotics/probiotics-and-prebiotics-english.

WHO (2017). Diarrhoeal disease. Retrieved from: https://www.who.int/news-roo$\mathrm{m} /$ fact-sheets/detail/diarrhoeal-disease. 